\title{
ABOUT AN EARLY MEDIEVAL SETTLEMENT IN THE SOUTH OF ANCIENT TOMIS
}

\author{
Cristina Paraschiv-Talmațchi
}

DOI: 10.17846/CL.2018.11.1.3-15

\begin{abstract}
PARASCHIV-TALMAȚCHI, Cristina. About an early medieval settlement in the south of ancient Tomis. The author makes a brief presentation of the discoveries from the tenth - eleventh century on the territory of Constanța (Constanța County, Romania; Pl. 1: 1), in the perimeter of the ancient settlement of Tomis. Based on these discoveries, it has been assumed until the present the existence of an early medieval settlement named Constantia, approximately within the same limits mentioned in the Byzantine literary sources. Related to the results of new discoveries in 2017, and comparing Tomis archaeological area with the discoveries in the researched site, we suggest a new location of the settlement of Constantia. It lies near a castellum of the stone vallum, in a protected area by the defensive line. Probably the new location of the settlement determined the reason for the Byzantine literary sources to mention it with a new name and not with the former toponym Tomis.
\end{abstract}

Keywords: settlement, Constantia, seals, ceramics, the 10th - 11th centuries, Dobrudja

\begin{abstract}
Abstrakt: PARASCHIV-TALMAȚCHI, Cristina. O včasnostredovekom osídlení na juh od antického mesta Tomis. Autorka podáva krátku prezentáciu nálezov z 10. až 11. storočia na území dnešného mesta Konstanca (župa Konstanca, Rumunsko; Pl. 1: 1), na hranici niekdajšieho antického osídlenia mesta Tomis. Na základe týchto objavov sa do dneška predpokladá existencia včasnostredovekého osídlenia, nazývaného Constancia, približne v rámci rovnakých hraníc, ako sú uvedené v byzantských písomných prameňoch. Nové výsledky objavov z roku 2017 a porovnanie archeologického priestoru mesta Tomis s objavmi na skúmanom nálezisku naznačujú možné nové umiestnenie osídlenia nazývaného Constantia. Ono ležalo blízko jednej z pevnôstok (castellum) kamenného opevnenia (vallum), na ploche chránenej obrannou líniou. Nové umiestnenie osídlenia pravdepodobne ovplyvnilo i dôvod, prečo ho byzantské písomné pramene spomínajú pod jeho novým meno a už nie pod niekdajším toponymom Tomis.
\end{abstract}

Klúčové slová: osídlenie, Constantia, pečate, keramika, 10. - 11. storočie, Dobrudža

The gradual disintegration of the Roman-Byzantine border on the Lower Danube, following the repeated Avar-Slav attacks in the second half of the sixth century and the beginning of the seventh century, had among the repercussions the decomposition of the urban life forms existing in the Danubian-Pontic territory, namely Dobrudja. The Empire's attempts to restore its position in the region and the need for some control points, both on the Danube and on the seaside, in order to stabilise the situation, provided an opportunity for some Dobrudjan centres to survive, in forms of the Roman-Byzantine culture, for a few decades in the seventh century (Madgearu 2013, 7; Damian, 2015, 11-19). Based on some numismatic and sphragistic findings, it was assumed that some centres from coastal Dobrudjan area continued to exist, in modest forms, until the beginning of the ninth decade of the seventh century (Damian 2015, 19). Among these 
settlements, we include Tomis (Constanța, Constanța County), the former capital of the late Roman province of Scythia Minor, whose episcopal seat became in Anastasius's time (491 - 518) a metropolitan seat (Barnea 1991, 278; Mănucu-Adameșteanu 1991, 299).

Until now, in the fortified perimeter of the ancient metropolis no habitation or other complexes have been discovered to show the existence of a continuous settlement form, from the time of destruction $(679-680)$ to the thirteenth century. A possible continuity of habitation between the level marking the end of the Tomis urban phase (ca. 613 - 614) and a fragment of precincts (dated to the thirteenth century, based on the building characteristics), which represents a completion or repair of the ancient precincts (Florescu 1968,29), has been conceived on the basis of numismatic, sphragistic and literary sources. In order to have a general view, in the following lines, we outline the state of research, emphasising the situation in the tenth - eleventh century that represents the period of interest for our study.

As mentioned above, the continued existence of the Tomis settlement until the end of the seventh century in the fortified perimeter (that means a peninsular protected area with a wall and a ditch on the northern side, easily accessible) was proved by numismatic and sphragistic discoveries. They include a gold ring on which the representation of two crossed hands, dated to the seventh eighth centuries, based on analogies (Gramatopol - Crăciunescu 1967, 149, pl. VII/8).

For a while in the past, it was considered that a paragraph from the notes of Patriarch Nicephoros (806 - 815), where the actions of the former Emperor Justinian II Rhinotmetos to return to the throne of the Byzantine Empire with the help of the Bulgarian Khan Tervel (held in 705), refers to Tomis, but he mentions it as a rural settlement (FHDR II 1970, 626-627; Barnea Ştefănescu 1971, 9). The same events are also presented in Theophanes Confessor's Chronicle, written in 810 - 814 (FHDR II 1970, 620-621; Mănucu-Adameşteanu 2017, 602). The in-depth analysis of the latter literary source has shown that this passage should be read eis stomin („in strait”) and not eis Tomin („Tomis”), which was a copying mistake (Tăpkova-Zaimova 1992, 49; Diaconu 1994, 353). So it seems that the reference was about a strait that links the Azov Sea to the Black Sea, not to a Tomis settlement (Diaconu 1994, 353).

There are literary sources where the information about conditions in the ninth century state the toponyms Tomis and Constantia. However recent studies consider that they either perpetuate the period situation from the previous centuries (Damian 2015,32), or refers to other geographical areas (Zugravu 1998, 151-156; Iordanov 2009, 570-571; Mănucu-Adameşteanu 2017, 603). Among them, we should mentioned the Notitiae Episcopatuum, A list 8 and C list 6, I, where Tomis appears as the eparchy of Scythia (FHDR II 1970, 638-639). In the notes of the monk Walafridus Strabus (804 - 849), based on the accounts of other monks believed to be worthy of faith, it is stated that the liturgical language in the region of Tomis was Gothic (FHDR II 1970, 640-641).

The clearest mention of the settlement on the western shore of the Black Sea is found in the work of Byzantine Emperor Constantine VII Porphyrogenitus De administrando imperio, written between 948 and 952. It is listed on the itinerary of the coastal road followed by the Russian one-trunk boats to Constantinople: “...From the Danube they head for Conopa, from Conopa to Constantia, then to Varnas, and from Varnas float towards the Ditzina river: all these (places) are on the Bulgarian lands..." (FHDR II 1970, 660-661). Specifying Constantia as a coastal settlement situated between the mouths of Danube and Varna, the chronicler proves the existence of the Dobrudjan settlement in the tenth century. Why Constantia is mentioned and not Tomis remains to be clarified.

Constanteia is also mentioned in the context of the siege of the Byzantine army, led by Emperor John Tsimiskes, at Dorostolon - Dristra (Silistra, Bulgaria), in the summer of 971. From Constanteia and other fortresses the messengers came to the Byzantine emperor to ask forgiveness and to surrender. Unclear expressions from the chronicles of Georgius Cedrenus [“... 
from Constanteia and other fortresses beyond Danube..." (FHDR III 1975, 140-141)] and Joannes Zonaras [„...from Constanteia and other fortresses...” (FHDR III 1975, 217)], both written in the eleventh - twelfth century, where no secure geographical positioning is given to them, left room for interpretation. It is often assumed that Constanteia is about the settlement on the western shore of the Black Sea, present-day Constanța (Diaconu 1970, 24, note 40; Madgearu 2007, 88; MănucuAdameşteanu 2017, 606).

Having the ancient city of Tomis been overlapped by the modern city, a systematic archaeological research in and around the fortified perimeter (in the peninsular area) was impossible. For this reason the archaeological evidence, on which statements regarding the existence and the special development of a probably fortified (Mănucu-Adameşteanu 2017, 618, 632) early medieval settlement (over the ancient one in its fortified perimeter), consists of fortuitous discoveries and results of preventive excavations. Of a certain provenance in this area, there are fragmentary ceramic pots made mostly of kaolin, including a bowl decorated with red paint (Cîrjan 1969, $375,387)$, and a bronze pendant cross with the geometric decoration dated to the tenth eleventh century (Mănucu-Adameşteanu 2017, 622). There is a small amount of ceramic material in in comparison with contemporary settlements. There are seven bronze coins that comes from the peninsula and three of them are directly from the port area. The only piece of gold, the solidus of Constantine VII - Roman II (945 - 959), has an attachment to be worn as a pendant, which dismisses its documentary value (Mănucu-Adameşteanu 2017, 622-623).

Although there are known some seals dated to the tenth - eleventh century discovered in Constanța, none of them can safely be assigned to the peninsular area (Barnea - Ştefănescu 1971, 15-19; Mănucu-Adameşteanu 1991, 319-320). However, the support of the discussion of the continuity of the settlement and possibly the preservation of its urban character is constituted on two Byzantine lead seals, probably discovered in Istanbul (Barnea 1991, 279281). The mentioned exemplars, kept at Dumbarton Oaks, belonged to metropolitans of Tomis and were chronologically framed on the basis epigraphic representations and characters (Nesbitt - Oikonomides 1991, 180-181). The first seal, dated to the tenth - eleventh century, belonged to metropolitan Anicetos (Avıкnं $\tau$ /Aniketos); the second one, dated to the eleventh

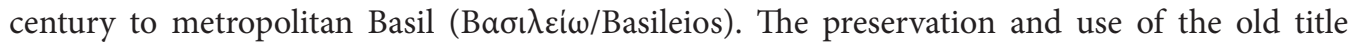
of "metropolitan of Tomis", which contain the ancient name of the settlement and not the name Constantia mentioned in the literary sources for the middle of the tenth century, was considered to be an indication of the revival of old Tomis in this period (Barnea 1991,281). The use of the old title suggests the maintaining of continuity in on the religious line.

Under the influence of the two seals attesting the existence of the Tomis Metropolitan Church, three other Christian objects (two of them come from a private collection, now in the patrimony of the Bucharest Municipal Museum) discovered on the territory of Constanța were attributed to a possible place of their discovery that is the peninsular area. The first one is a golden ring (dated to the nine - tenth century), which was made from a bar with a semi-circular section, with an irregular octagonal shape and it was engraved by the inscription IHCOY XPHCTOC (Mănucu-Adameşteanu 2017, 621). The second exemplar is a bronze ring, dated to the eleventh century, with a semicircular and oval chaton that bears the incised inscription $+\mathrm{K} \Sigma \mathrm{BOH} \Theta \mathrm{ETO}$ KO $\triangle$ PANTO (God helps Kodrato) an it is framed by a border of stitches (Mănucu-Adameşteanu 1991, 320). The last object, dated to the end of the tenth century and the eleventh century, represents a relatively frequent discovery in the Dobrudja region. It is the obverse of a reliquary bronze cross, on which crucified Jesus Christ clothed in collobium is embossed. Above the head bent slightly to the right, there is a small cross with arms of equal lengths (Mănucu-Adameşteanu 1992, 349). 
In this stage of research it is difficult to state whether or not the settlement, the seat of the metropolitan, was in the perimeter of the ancient settlement, namely in the peninsula. The above-mentioned discoveries, between 1950 and 1970, were mostly accidental (except ceramics, a cross and a coin). Subsequently, only one coin was discovered in 1995, namely at the foot of a modern house. I is a local tradition connected with the prosperity of a new construction. Preventive excavations of the past three decades, which was made selectively (some of them on worthwhile spots) in numerous sites disposed across the peninsula, did not reveal material or dwelling traces of the early medieval period.

Recently, in the autumn of 2017, the building of a block of flats (in Constanța, 8, Aleea Scafandrilor) gave us the opportunity to explore a small part of a settlement from tenth - eleventh century, located about $2 \mathrm{~km}$ to the south - southwest of Tomis' ancient precincts (Pl. 1:2). In 1986, about $350 \mathrm{~m}$ to the north - northwest of the perimeter investigated by us, several other complexes of the same period were discovered. Since the two areas are part of the same site, we will also refer to discoveries of the year 1986. The two points sum up nine habitation complexes (some of them were surprisingly uncovered partly, because they came out of the perimeter under investigation and entered neighbouring properties or were partially destroyed in the past by anthropic activities), two of them with a workshop character and there were also some graves.

Generally, in the area investigated in 2017 the site stratigraphy was the following: the vegetal layer, with a thickness ranging between 0.05 and $0.15 \mathrm{~m}$; followed by a layer of modern deposits (from decommissioned constructions or domestic debris), 0.30-0.65 m thick; then a brownishgrey, slightly granular, without a large amount of early medieval material (except complex areas), whose thickness was $0.40-0.80 \mathrm{~m}$; it was followed by a yellow-brown level (0.20-0.30 m thick) with numerous galleries made by moles and mice and with no archaeological material; in the end it was loess.

Following the research, eight complexes were identified, on a 1,000 sq $\mathrm{m}$ area; they represent dwellings and constructions (rooms) with a workshop character. No overlapped complexes were observed; there were only some rebuilt ovens, household buildings outside the dwellings (ovens and supply pits) and periodic household pits found in most of the sites. A small number of the identified complexes and the production character of them determines that we face the south-eastern boundary of the settlement.

The six dwellings discovered in this point and one of the constructions with a workshop character belong to the type of semi-sunken dwelling. Out of a total of eight complexes, only a workshop was raised from the ground. At the point investigated in 1986 (situated in Boulevard 1 Mai, block of flats J2A, to the west of the Stadium Portul) there were identified two sunken dwellings and one above-ground dwelling. Overall, the methods of construction of the dwellings and workshops are similar to those attested in other settlements of the same period, and not only in the Dobrudja area.

Sunken dwellings from the settlement of Constanța, the point of Aleea Scafandrilor, had a rectangular pits or pits of irregular shapes. It began from the early medieval layer and stopped in loess, the sunken part was at a depth of $0.50-0.70 \mathrm{~m}$. The pits represented the inner residential surface and they consist of compacted yellow earth with thickness of $0.03-0.04 \mathrm{~m}$. Generally, they measured from about $8 \mathrm{sq} \mathrm{m}$ to $12.5 \mathrm{sq} \mathrm{m}$, which is calculated according to their interior residential surface. Over the surface, the sunken dwellings had a wooden skeleton to support a gable roof; at the same time, the wooden skeleton was the base on which surface walls used to be arranged. In five sunken dwellings pit beams were observed. In one completely surveyed sunken dwelling we noticed that the pit beams were arranged in alignment with the sides or the middle of the room. Discoveries of clay fragments with imprints of reeds and straw in the filling of some mentioned sunken dwellings reveal that the walls were made of wattle overlapped by yellow clay. 
The presence of an ash layer, which is the result of the burning of lightweight materials and which followed the fire of several complexes, proves the use of a reed for roofs. In one of the sunken dwellings discovered here, complex 7, there was the south wall of its pit that was covered by stones. The wall was kept, in elevation, on three or four rows of stones (at the height of $0.50 \mathrm{~m}-0.65 \mathrm{~m}$ ). The poles, which reinforced the wall, were $0.10 \mathrm{~m}$ thick. Large and medium-sized stones were tied with yellow clay and placed in one thick row. Among them, there was an architectural fragment that came from an ancient building (the second architectonic marble fragment was fallen near the wall). Also, the sunken dwellings covered by stones on the inside are less frequently discovered in Dobrudja, but they usually appear in early medieval settlements which overlap or are close to those from Antiquity (in our case it is Tomis).

Apart from the almost similar constructions of the mentioned dwellings, we can observe some differences in the form of a heating system. Heating systems were placed in one of the corners or sides of a dwelling, then they were hollowed out in one wall of a dwelling or they were built of stones. One isolated dwelling (Complex 5) had a domed oven in its southwest corner. At the time of the discovery, it kept its height of $0.43 \mathrm{~m}$ (its dome was collapsed inwards) and its walls were $0.04 \mathrm{~m}$ thick. The fire pit of this oven, which measures $1.25 \times 1.08 \mathrm{~m}$, was made of strongly burnt and cracked yellow clay. It was restored and widened to the rear and the old fire pit was $0.16 \mathrm{~m}$ deeper. The mouth of the oven, whose opening is $0.35 \mathrm{~m}$ wide, was oriented to the northeast. Other ovens, which were built of stone, were rectangular in shape. As the case might be, they were mostly on the western half of the northern side, in the northeastern, or the southwestern corner of the dwellings. None of the ovens made out of stone was found complete, in elevation. At the moment of the discovery the walls of these ovens were kept, in elevation, at most on two rows of stone (at the height of $0.25-0.30 \mathrm{~m}$ ). Their surface varied between $0.66 \times 0.50 \mathrm{~m}$ and 0.75 $\mathrm{x} 0.65 \mathrm{~m}$. Two of them were placed near the gap of stone arrangements made to protect the interior of dwellings.

Regarding the rational arrangement of space, so that it would be suited well its purpose, in two of the sunken dwellings there were observed massive stone arrangements ( $\mathrm{Pl}$. 2:2), possibly a table or places of storage (Pl. 2: 1). In the first case, an almost oval stone block $(0.90 \times 0.62 \mathrm{~m})$, placed on a compact yellow clay hollow, was situated in the centre of the room (slightly to the south), so it was easy to go round it (probably a table). The second case represents the following situation. Between the fire pit of the oven and the western wall of the dwelling four large stones were placed. They are relatively flat and form an area of $0.50 \times 0.50 \mathrm{~m}$ - probably the special arrangement to store some objects (e.g. pottery). The entrances into the sunken dwellings were on their western or northwestern sides (depending on their orientation). Remains of clay stairs covered by planks were unearthed in one of the mentioned complexes, as it is shown by the remaining holes to fix them.

The only one surface construction raised over the ground (Complex 4) has the character of a workshop. It was irregular in shape (with five sides) and covers an area of about $14 \mathrm{sq} \mathrm{m}$. The essential part of its interior was occupied with an oven. Its sides are delimited by rows of stones and on the northern side, near the oven, there are two rows of stones and a floor of compacted clay. The entrance into the dwelling $(0.80 \mathrm{~m}$ wide $)$ was on the northwest side. It is well defined by slightly lower deposition of stones in comparison with stone rows in relation to the walls and their considerably worn-out appearance. The oven was placed towards the northeast corner and almost touched the northern wall. The construction with clay walls, which was reinforced on its eastern border with stones ( $0.05 \mathrm{~m}$ thick and $0.17 \mathrm{~m}$ high), benefited from two refurbishments and a change of its soil footprint. All fire pits found there were strongly burned and cracked. The first one (from the bottom up) was slightly oval in shape and has surface area of $1.60 \times 1.50 \mathrm{~m}$. In front of the mouth of the oven, towards the southwest, there was an intensely 
reddish area, which was $0.60 \mathrm{~m}$ long. The mentioned oven was built $0.28 \mathrm{~m}$ from the northern side and $0.63 \mathrm{~m}$ from the eastern side of the dwelling. There was another fire pit, which was also made of compacted clay and it was placed at a distance of $0.08 \mathrm{~m}$ above the aforementioned fire pit of the oven. It represents the first restoration and the movement of the oven's footprint (by its retraction) to the northern wall and the orientation of the oven's mouth towards the southeast. The new oven has a surface area of $1.40 \times 1.45 \mathrm{~m}$. The last fire pit, located $0.04 \mathrm{~m}$ above this oven, was also made of compacted clay and kept the footprint and the size of the second oven.

At the point, which was investigated in the autumn of 2017, were not any ovens with a fire pit made of compacted clay mixed with small stones, or with a ceramic bed that was covered by clay, or even made of reused Roman paving slabs as they can be found in other contemporary settlements (Paraschiv-Talmațchi 2014, 8, 11; Paraschiv-Talmațchi, Talmațchi, Bodolică 2015, 401).

In relation to kinds of artefacts found in all early medieval settlements in Dobrudja and their quantity, pottery was the most numerous artefact discovered there. From a point of view of functionality, pottery included categories that we were usually able to encounter in other settlements of the analysed period (Doncheva-Petkova 1977, 33-110): kitchen dishes, tableware, and containers for storage and transport.

The largest category within the aforementioned pottery is pottery moulded from common paste and finished in an oxidation firing (Pl. 3: 1-11). It was made on a slow- or fast-turning wheel. In general, discovered pottery was not fired to its core (its core is in grey) and just few exemplars were fired properly (in the colour of brick or yellow-brick). Pottery was mostly decorated by the technique of incision, namely with horizontal lines and over them - in the shoulder area of a vessel - there were drawn strips of lines in the shape of waves or beams of oblique lines in different sizes. Several fragments were incised with alveoli or notches that were arranged in the form of a string over horizontal lines. A string sometimes overlapped them in their upper parts. A few fragments made of fine paste have a polished decoration (of vertical lines). One single fragment, small in size, was decorated on its outer surface with olive green and yellowish enamel. The fine paste pottery, produced in a reduction firing (with shades of light grey and black), were created on a fast- or slow-turning wheel. This kind of pottery was rare among other discoveries (and only in sherds). It was ornamented by the technique of polishing, with oblique lines arranged in a net or with horizontal mechanical polishing. Vessel, which fit into all three functional categories mentioned above, were made of common paste. Typically, they are distributed as follows: pot without handle/jar (kitchen utensils); amphora-shaped jug (tableware); pots without bigger size handles and amphora (vessels for storage and transport). Various pottery stamps were applied (Pl. 3: 10-11) on the bottoms of four vessels made of common clay and various signs were incised on amphora-shaped jugs and amphorae. The amphorae discovered in the referred point are all in a fragmentary state and belong to the type of a spherical amphora and amphora that is pyriform in shape and has a collar (Günsenìn 1990, fig. 3). The first type is dated to the second half of the tenth century and the eleventh century, and the pyriform exemplars with a collar, are dated at the end of the tenth century and to the eleventh century (Paraschiv-Talmațchi - Custurea 2015-2016, 256).

Kaolin pottery was made on a slow- and fast-turning wheel. It was produced in an oxidation firing - proper one or insufficient (without a depth). This pottery was decorated by the incision technique or with red paint (Pl. 3: 12-13). On some pottery two techniques were combined. Thus, a fragment that comes from the body of a pot without a handle was incised by horizontal lines on the outside of a rim, over which strips were painted by red paint. The types of vessels that belong to this category, referring to the research stage, are: a pot without handles and a jug.

In addition to a ceramic vessels discovered in the given settlement, there is an abundant and diverse archaeological material that comes from various complexes and a particular layer. This 
material consists of: bone artefacts (awls, fragments of unspecified bone artefacts); iron artefacts (spikes); other ceramic objects (sling balls, spindle whorls, fragmentary weights for a fishing net, shingle bricks used to sharpen bone objects); stone industry (probably the end of a battle whip, whetstone to sharpen metal objects, fragmentary anchors), archeofauna, etc. During the research we did not find coins.

In order to complete the image of the settlement, we should mention that ovens dug into the ground were discovered outside the sunken dwellings at the point investigated in 1986. They were probably fitted with access pits and their surface area measured about $0.80 \times 1 \mathrm{~m}$. (MănucuAdameşteanu 1991, 318).

On the same site, graves were also discovered. In some of them a stone cist or Roman brick was reused. The inventory of the graves was rather modest, although the found grave goods refer only to two graves (grave M1 - an applied ornament and a bronze earring; grave M2 - a pot without handles, which was made of coarse paste, was deposited in the area of the head of the deceased). We assume that the rest of the graves did not contain any grave goods (Irimia - Cliante 1986, 184; Mănucu-Adameşteanu 2017, 612-613).

Outputs of the archaeological excavations that were carried out in the two points (researched in 1986 and 2017) lead us to claim that they were part of the same settlement that was formed around a castellum of the stone vallum. It is one of the three linear fortifications that cross the territory of Dobrudja from west to east. The stone vallum starts from the south of Cernavodă and stops on the high coast of the seaside, to the south of ancient Tomis. It crosses the territory of Dobrudja through its narrowest point as well as largely accompanies the natural obstacle of the old Carasu valley, then reinforces it and makes it difficult to be passed. Evliya Çelebi wrote in the seventeenth century about the stone vallum. Since the nineteenth century this construction has attracted the attention of some researchers, engineers, or archaeologists. Its best records were made by Grigore Tocilescu and Carl Schuchhardt (Tocilescu 1900, 157-163; Schuchhardt 1918, 28-55). Thanks to them, today we know that the stone vallum had the length of $59 \mathrm{~km}$ and at the time of its recording it was still $1.50-2 \mathrm{~m}$ high. To the north it was protected by a $10 \mathrm{~m}$ long trench, whose kept depth varied between 2 and $3 \mathrm{~m}$, while its rampart and the trench were $25-30 \mathrm{~m}$ wide together. The stone vallum has 26 castellums, most of them located in the south. Gr. Tocilescu recorded them, from west to east (the first castellum was on the Danube), while C. Schuchhardt started from Constanța, where castellum I was on the Black Sea coast. Although the stone vallum was initially considered to be a Roman period construction, now it is attributed to the early medieval period (Barnea - Ştefănescu 1971, 100-104; Damian 2015, 56-62).

The analysis of the vallum path in the maps drawn up at the beginning of the twentieth century, corroborated with the information provided by the extensive studies dedicated to the defensive alignment, determine us to assume that the presented settlement was formed around the XXVI Tocilescu/I Schuchhardt castellum. Actually, in all the camps of the stone vallum, it was observed habitation, for the mentioned period, and even the emergence of large settlements around the camps. A considerable size settlement was investigated in 2010 - 2011 at Valu lui Traian (Constanța County), which was formed around and in the XXII Tocilescu/IV Schuchhardt castellum (Paraschiv-Talmațchi 2014, 13-15).

The castellum in Constanța (probably it was originally square in shape) was a part of the midto-large camps of the stone vallum and its sides were $247 \mathrm{~m}$ long (to the north and west). We used the adverb "probably" in the previous compound sentence because at the time of the registration of this castellum (made by Karl Friedrich von Vincke in 1839 - 1840) its square form was mentioned. But we should also take the following fact into consideration - the southern side of the castellum was later recorded as $187 \mathrm{~m}$ long (Tocilescu 1900, 179-180). At the same time, it is made clear that to the east, the camp did not need a wall, as the steep and rocky shores 
of the coast line constituted themselves a natural shield (Tocilescu 1900, 180). Grigore Tocilescu took the referred data from Karl Friedrich von Vincke because at the time of his records (he worked the topographer Pamfil Polonic), at the end of the nineteenth century and the beginning of the twentieth century, the given castellum had been already demolished by "the inhabitants who settled around the new city of Constanța", by reason that there used to be "the vineyards of the city" (Polonic 1935, 24).

Referring to the results of the new research and a comparison between the archaeological situation in the peninsular area and the situation around the XXVI Tocilescu/I Schuchhardt castellum, we are surprised that the representative early medieval settlement of the area was actually there. The characteristics of the complexes and the ceramics in the perimeters in Aleea Scafandrilor Street and Boulevard 1 Mai in Constanța reveal a tenth century habitation, which also lasted in the first decades of the eleventh century. Probably the new location of the settlement, to the south of the wall - the protected stone vallum - and not in the ancient perimeter that was left to the north of the defensive alignment, determined accounts of the settlement with the new name - Constantia - in the Byzantine literary sources. Unfortunately, much of the site was destroyed in the course of time by the building of various constructions. Another part of the site is under the Stadium Portul, built almost six decades ago. It will be difficult in future to prove the level of development achieved by this settlement. Some of the discoveries in private collections might have come from this area because they were found during works in vineyards and other places or on other occasions. It is also plausible that a small amount of archaeological material dated in this period, which was found in the area of the ancient settlement, could have been brought there, at least partially by those people who took blocks of stone and architectural fragments from the ancient constructions of Tomis (Tocilescu 1900, 158-159) in order to use them for the building of the stone vallum's wall. Obviously, our considerations are related to the current state of research, and discussions cannot be exhausted as long as archaeological research has a limited deployment framework.

\section{REFERENCES}

\section{Primary sources}

FHDR II. 1970. Mihăescu, Haralambie et al. (eds.). Fontes Historiae Dacoromanae, II. Scriptores: 2. Ab anno CCC usque ad annum M. Bucureşti.

FHDR III. 1975. Elian, Alexandru - Tanaşoca, Nicolae-Şerban (eds.). Fontes Historiae Dacoromanae, III. Scriptores Byzantini. Saec. XI-XIV. Bucureşti.

\section{Secondary sources}

Barnea, Ion. 1991. Noi date despre mitropolia Tomisului. In Pontica 24, 277-282.

Barnea, Ion - Ştefănescu, Ştefan. 1971. Din istoria Dobrogei, Vol. III. Bizantini, români şi bulgari la Dunărea de Jos. Bucureşti.

Damian, Oana. 2015. Bizanțul la Dunărea de Jos (secolele VII-X). Brăila.

Diaconu, Petre. 1970. Les Petchénègues au Bas-Danube. Bucarest.

Diaconu, Petre. 1994. Note de lector (II). Unul sau două Tomis-uri în bazinul Mării Negre?. In Istros 7, 353-354. 
Doncheva-Petkova, Ljudmila. 1977. Българска битова керамика. През ранното средновековие (втората половина на VI - края на X в.) [La céramique domestique bulgare pendant le haut Moyen Âge (la seconde moitié du VI à la fin du X ${ }^{\mathrm{e}}$ s.)]. София [Sofia].

Florescu, Radu. 1968. Ghid arheologic al Dobrogei. Bucureşti.

Gramatopol, Mihai - Crăciunescu, Virgilia. 1967. Les bijoux antiques de la Collection Marie et Dr. G. Severeanu du Musés d'Histoire de la Ville de Bucarest. In Revue Roumaine dHistoire de l'Art 4, 137-171.

Günsenin, Nergis. 1990. Les amphores byzantines ( $\mathrm{X}^{\mathrm{e}}-\mathrm{XIII} \mathrm{I}^{\mathrm{e}}$ siècles): typologie, production, circulation d'après les collections turques. The Doctoral Thesis. Université Paris I (PanthéonSorbonne). Atelier national de reproduction des thèse de Lille III. Paris.

Iordanov, Ivan. 2009. Corpus of Byzantine seals from Bulgaria, Vol. 3. Parte One. Text. Sofia.

Madgearu, Alexandru. 2007. Organizarea militară bizantină la Dunăre în secolele X-XII. Târgovişte. Madgearu, Alexandru. 2013. Byzantine Military Organization on the Danube, 10th-12th Centuries. Leiden - Boston.

Mănucu-Adameşteanu, Gheorghe. 1991. Tomis - Constantia - Constanța. In Pontica 24, 299-327.

Mănucu-Adameşteanu, Gheorghe. 1992. Cruci relicvar de tip bizantin descoperite în sudul Dobrogei. In Pontica 25, 349-354.

Mănucu-Adameşteanu, Gheorghe. 2017. Monede bizantine descoperite în nordul Dobrogei, secolele VII-XIII. Bucureşti.

Nesbitt, John - Oikonomides, Nicolas (eds.). 1991. Catalogue of Byzantine Seals at Dumbarton Oaks and in the Fogg Museum of Art, Vol. 1. Italy, North of the Balkans, North of the Black Sea. Washington, D.C.

Paraschiv-Talmațchi, Cristina. 2014. Noi contribuții la repertoriul arheologic medieval timpuriu dobrogean. In Analele Universității „Dimitrie Cantemir”, SI. 5/3-4, 6-37.

Paraschiv-Talmațchi, Cristina - Talmațchi, Gabriel - Bodolică, Vitalie. 2015. O nouă aşezare medievală timpurie la Hârşova (jud. Constanța). In Ciupercă, Bogdan (ed.). Arheologia mileniului I p.Chr., Vol. IV. Nomazi şi autohtoni în mileniul I p.Chr. Brăila, 397-423.

Paraschiv-Talmațchi, Cristina - Custurea, Gabriel. 2015-2016. Nouvelles données sur les découvertes sous-aquatiques du littoral roumain. In Pontica 48-49, 241-279.

Polonic, Pamfil. 1935. Valurile antice din Dobrogea. In Natura 24/6, 21-26.

Schuchhardt, Carl. 1918. Die Sogenannten Trajans Wälle in der Dobroudscha. Berlin. 1918. Extracted from Abhandlungen der preussischen Akademie der Wissenschaften. Philol.-hist. Klasse 12, 1-66.

Tăpkova-Zaimova, Vasilka. 1992. Българите по Северното причерноморие до Х в. [Bulgarians from the northern coast of the Black Sea until the $10^{\text {th }}$ century]. In Българите в северното причерноморие, Исследования и материали [Bulgarians on the northern Black Sea coast, Investigations and materials], Том I. Велико Търново [Veliko Tarnovo], 47-56.

Tocilescu, Grigore. 1900. Fouilles et recherches archéologiques en Roumanie; communications faites à l'Academie des inscriptions et belles-lettres de Paris, scéance du 27 octobre 1899. Bucarest, 145-184.

Zugravu, Nelu. 1998. Deux notes de géographie ecclésiastique. In Cercetări istorice 17/1, 151-161.

SUMMARY: ABOUT AN EARLY MEDIEVAL SETTLEMENT IN THE SOUTH OF ANCIENT TOMIS. The gradual disintegration of the Roman-Byzantine border on the Lower Danube, following the repeated Avar-Slav attacks in the second half of the sixth century and the beginning of the seventh century, had among the repercussions the decomposition of the urban life forms in the Danubian-Pontic territory, namely 
Dobrudja. Based on the numismatic and sphragistic findings, a continuous existence of some centres on the coastal Dobrudjan area, including Tomis (the former capital of the Roman province Scythia Minor) was assumed, until the beginning of the ninth decade of the seventh century. Then, a possible continuity of habitation between the level marking the end of Tomis urban phase (ca. $613-614$ ) and a fragment of precincts dated to the thirteenth century has been so far conceived on the basis of numismatic, sphragistic and literary sources. In the autumn of 2017, the construction of a block of flats gave us an opportunity to explore a small part of a settlement from the tenth - eleventh century, located about $2 \mathrm{~km}$ to the south southwest of Tomis' ancient precincts. Referring to the results of the new research and a comparison between the archaeological situation in the Tomis area and the situation in the point studied in 2017, we suggest a new location for the settlement of Constantia that is mentioned in the Byzantine literary sources from the middle of the tenth century. It lies near a castellum of the stone vallum, in a protected area of the defensive line. Probably the new location of the settlement also determined its registration in the Byzantine literary sources with the new name, and not with the toponym Tomis.

Ph. Dr. Cristina Paraschiv-Talmațchi

Museum of National History and Archaeology

Piața Ovidiu 12

Constanța, 900745

Romania

ctalmatchi@gmail.com 


\section{Appendix / Prílohy:}
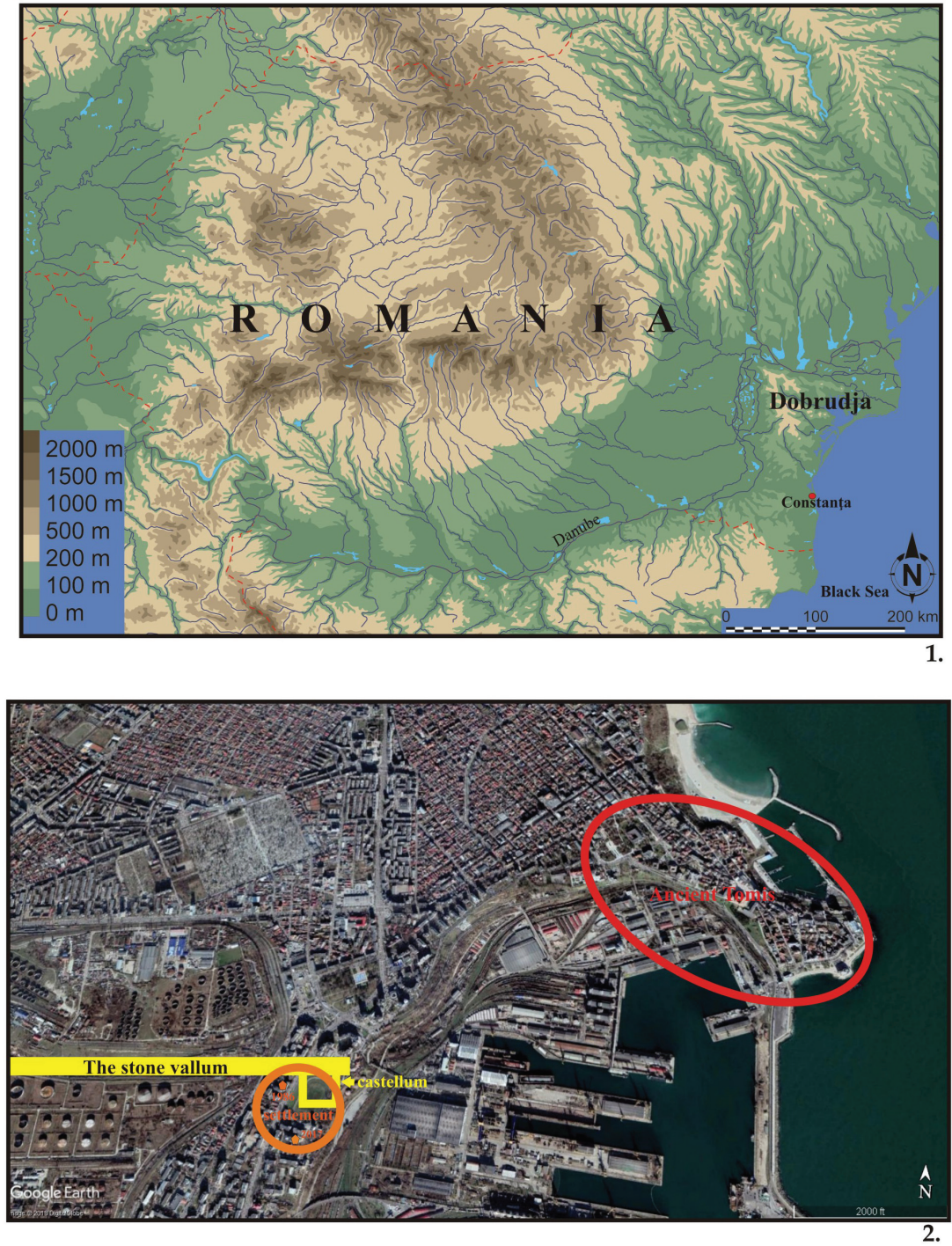

Plate 1. 1. The administrative position of Constanța (Constanța County, Romania); 2. The location of ancient Tomis and an early medieval settlement as well as its two excavated spots (in 1986 and 2017) in the plan of the city Constanța.

Tabulka 1. 1. Administratívna pozícia Konstance (župa Konstanca, Rumunsko); 2. Umiestnenie antického mesta Tomis a včasnostredovekého osídlenia ako aj jeho dvoch skúmaných miest (v roku 1986 a 2017) na pláne mesta Konstanca. 


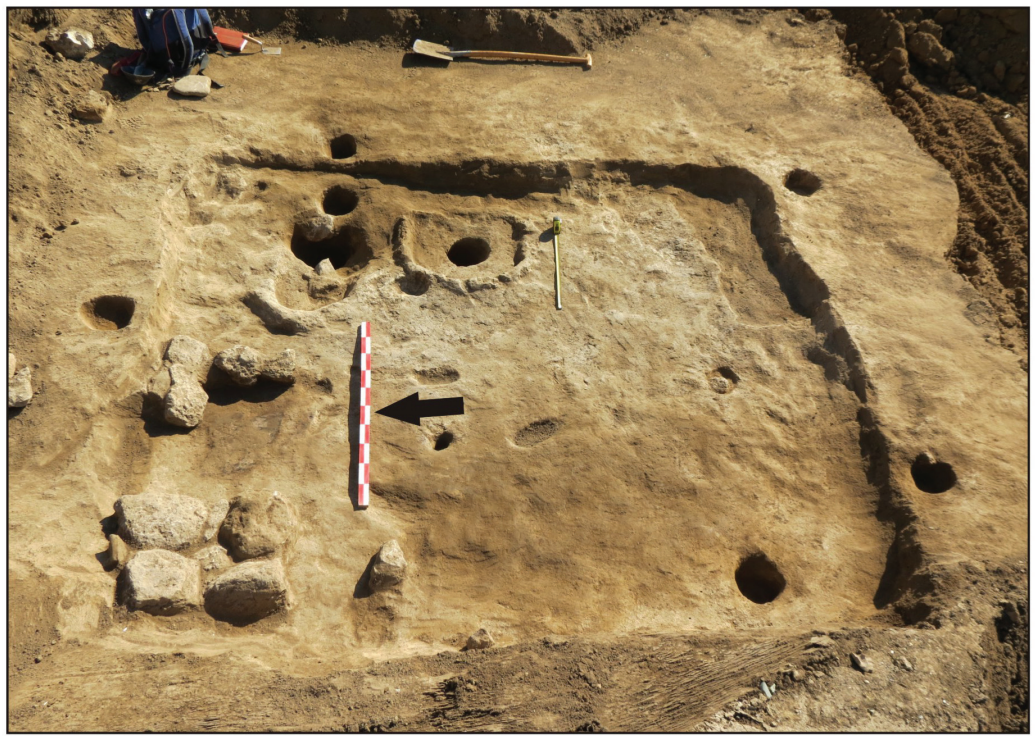

1.

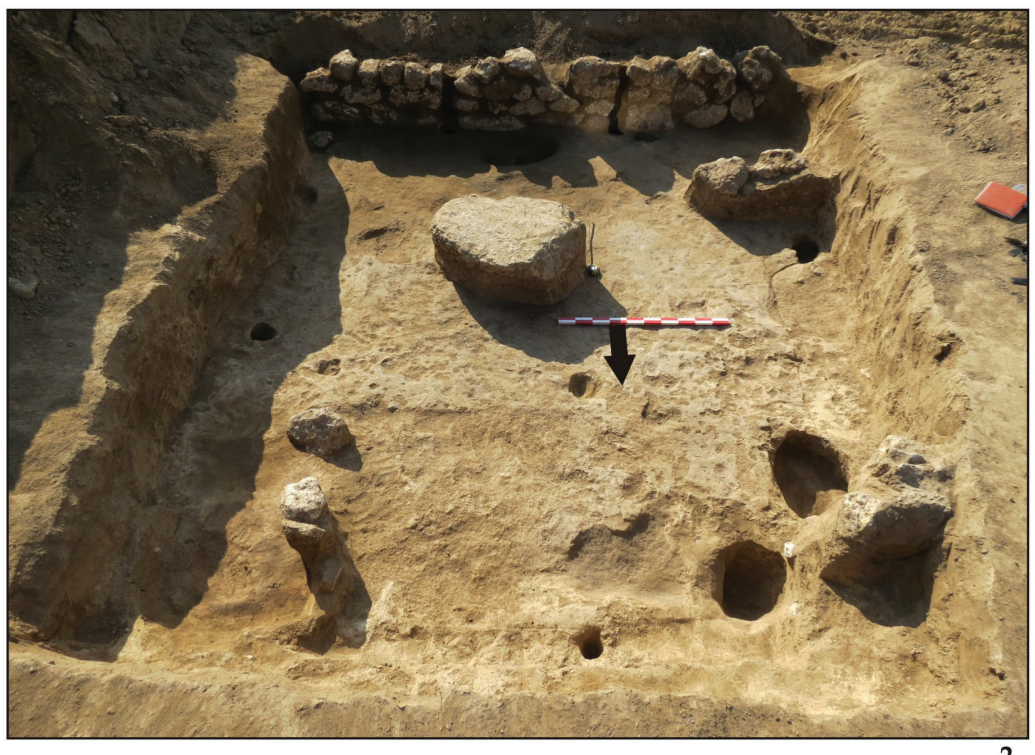

2.

Plate 2. Sunken dwellings discovered in the early medieval settlement of Constanța - 1. Complex 6; 2 . Complex 7.

Tabulka 2. Zahĺbené obydlia nájdené na včasnostredovekom sídlisku v Konstanci. 1. Celok 6; 2. Celok 7. 


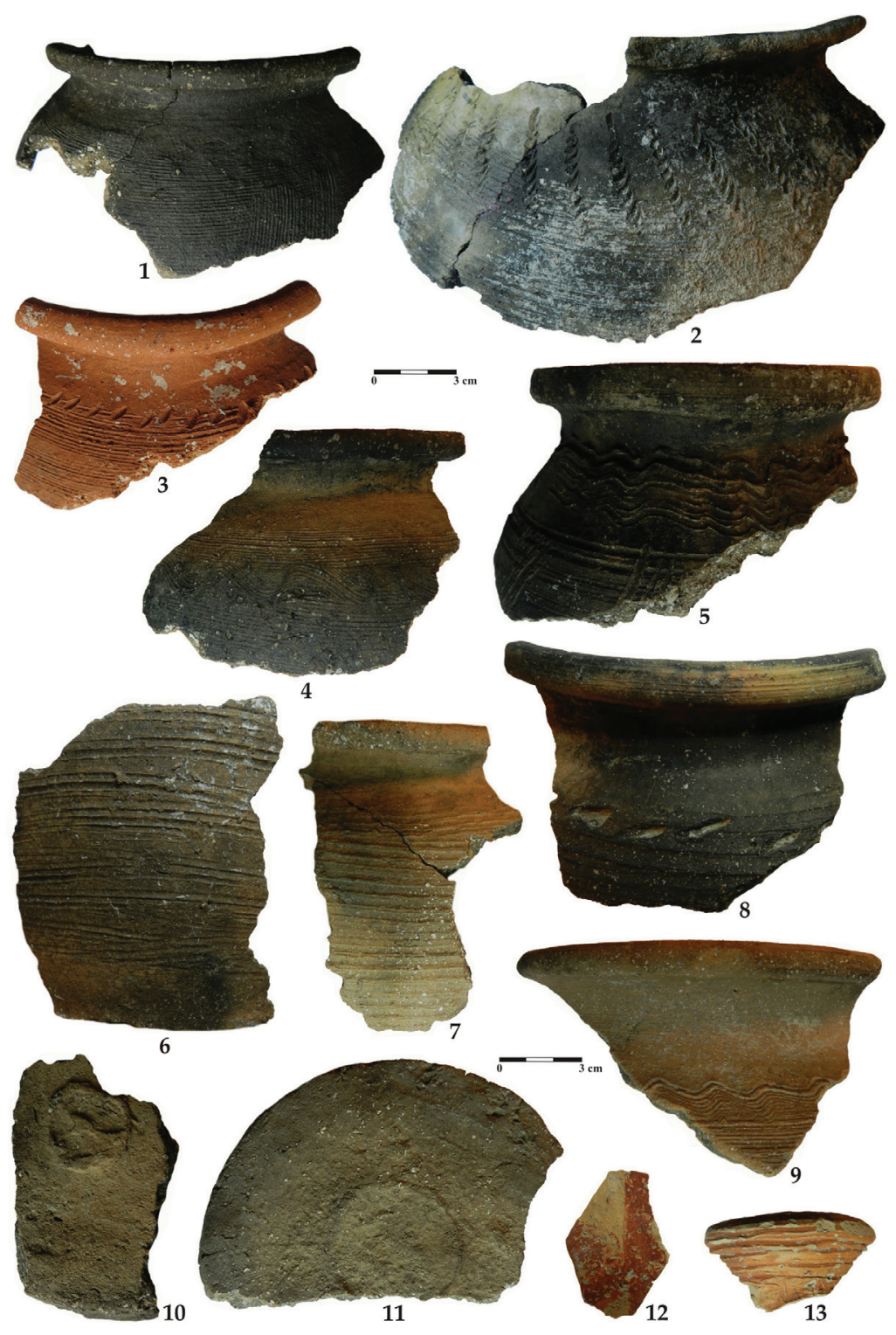

Plate 3. Pottery discovered in the early medieval settlement of Constanța.

Tabulka 3. Keramika objavená na včasnostredovekom sídlisku v Konstanci. 